\title{
Small Scale Farmers' Knowledge on Grain Losses from Bean Bruchid, Pesticides Safe Use and Implication on Food Security and Safety in Huye District, Rwanda.
}

\author{
${ }^{1.3 . S . ~ U m u b y e y i ~, ~}{ }^{2}$ N.D.T.M. Rukazambuga \\ ${ }^{1}$ Agricultural Officer, Huye District, P.O. Box 35, Butare, Rwanda.

\begin{abstract}
${ }^{2}$ University of Rwanda, College of Agriculture, Animal Sciences and Veterinary Medicine (CAVM), School of Agriculture, Rural Development and Agricultural Economics (SARDAE), Department of Crop Science. P.O. Box, 117, Butare, Huye District, Rwanda, email. dnrukazambuga@gmail.com.
\end{abstract}

\begin{abstract}
The common bean is the most important grain legume in Rwanda, as a source of $40 \%$ protein, playing a significant role in human nutrition, food security and income. Bean bruchid is a major constraint in stored grains, reducing both quantity, quality and storage period. The study aimed at establishing farmers knowledge on bean bruchid problem, pesticides safe use, and hazardousness. We conducted a study using 91 farmers selected randomly in Rwaniro Sector, from four villages as follows: 23 farmers per village for Gatwaro, Rumana and Amarongi, and 22 farmers in Nyakabuye. We used questionnaires and face to face interviews to collect data on bean bruchid, control methods, pesticide use and safety measures. The results indicate that farmers experienced high bruchid infestation starting three months after harvesting. $37.4 \%$ lost up to $30 \%$ of grains, $17.6 . \%$ lost up to $50 \%$, and $17.6 \%$ lost more than $50 \%$. The loss was quite variable and depended on storage period and conditions. The grain loss causes shortage, food insecurity, high prices and reduced intake; denying farmers' s access and affordability. In this study, $53.9 \%$ of farmers used pesticides, while they were not trained on safe use, as a result $99 \%$ of them cooked and sold treated grains without waiting for recommended post treatment period. Other traditional control methods used include ash, lime and pepper flour but their effectiveness is not clearly documented. We recommend focused training on pesticides safe use for food security and safety, and also development of different bruchid
\end{abstract}


control techniques and dissemination mechanism to smallholders. Since beans are next to meat in food security and nutrition under Rwanda context, bruchid damage is a major challenge in the country...

Keywords: Beans, Bruchids, Pesticide Control

\section{Introduction.}

The common bean (Phaseolus vulgalis L.) is a major source of protein for about 70 million people in the world (FAOSTAT, 2013). In 2013, the eastern and southern Africa countries produced $16 \%$ of the world bean production, and Rwanda produced 438,236 MT and ranked 10th in the world (FAOSTAT, 2013). In Rwanda, beans are among important staple crops for food security and nutrition, as a major source of both protein (20$30 \%$ in dry beans) and caloric intake (32\%) (Sparling and Muyaneza, 1995). The annual mean consumption per capita is $29 \mathrm{~kg}$ (Musoni, 2012), making Rwanda, one of the highest bean consumer in the world (Catherine and Jeffrey, 2014), a confirmation that beans are important food security crop (Catherine and Jefrey, 2014) in the country. Since land shortage is key challenge in Rwanda, the production of beans as source of protein is the best option, because, one hectare planted with beans in Latin America produces $123 \mathrm{~kg}$ of protein as compared to 3-4 $\mathrm{kg}$ produced by beef cattle reared on the same size of land (Jones, 1999). There are two types of beans produced in the country based on growth habits; (i) the bush and (ii) climbing types. The bush type is predominant at low altitude up to about 1700 masl, which may vary depending on latitude position; while the climbing type is adapted to medium and high altitude ( above 1700 masl).. The mapping of limitation for both types in Rwanda is unclear, and sometimes causes confusion among farmers. For example, before wide distribution and promotion of climbing beans, the farmers in Nyamagabe District, at Gasarenda centre, an altitude about 2000 masl, did not understanding while they cannot produce bush beans while in Huye District ( about 1700 masl) produce them. Likewise, the relationship of altitude and level of bruchids infestation is unclear, moreover, there are also two 
species of bruchids:.(i) bean bruchid (Zabrotes subfasciatus) (Boheman) and (ii) mexican bean weevil, Acanthoscelides obtectus (Say) (Abate and Ampofo, 1996) which have difference in altitude limitation...

The stored common bean grains are attacked by the above mentioned two species of bruchid causing significant high losses in all continents, and greatest in developing countries where storage facilities are usually not good or unavailable (CIAT, 1986). Farmers store beans for mainly food security and for selling at higher price during off season. A good storage in a dry place below $12 \%$ moisture content (MC) preserves quality of beans, by keeping them in a state of dormancy, as a result the grains remain viable for prolonged periods (De Lucia and Assenato, 1994). The major constraints of stored beans are both bruchid and microorganisms (De Lucia and Assenato, 1994). The bruchid damage causes deterioration of grains, lowers quality and marketability, hence loss of income and food security (Jones, 1999, Abate and Ampofo, 1996). The damage of grains affects directly the final product and the grain cannot recover like damage on the growing plant in the field. Damage caused by bruchid falls into four categories: (i) bored holes in the kernels and disappearance of large portions in the inside of kernels; (ii) injury to the germ resulting in loss of seed germination; (iii) heating and subsequent moisture condensation causing moulds to grow and (iv) contamination of the grain mass with excrement, cast skins, and webbing. As consumers continue to demand higher quality grains, it is increasingly important to prevent contamination and deterioration during storage. Understanding the insects and microorganism behaviour, and conditions (temperature and moisture) favouring their growth is the key for effective bean bruchid control (Abate and Ampofo 1996). There are two main bruchid species causing damage to stored bean grains: (i) bean bruchid (Zabrotes subfasciatus) (Boheman) and (ii) mexican bean weevil (Acanthoscelides obtectus)(Say). Both species belong to the order Coleoptera in the family Bruchidae. The Zabrotes spp. attack beans in storage only, while Acanthoscelides spp starts in the field on late harvested pods and continue in store (Howe and Currie, 1964, Haines, 1991). The two species cause direct and indirect losses to farmers. The direct loss being a result of 
damage and related losses, while indirectly loss being forcing farmers to sell their grains soon after harvesting when prices are low, generating small income.

In Rwanda and Burundi, grain losses are about 30\%, while in Mexico and Central America the loss is 35\%, and in Ethiopia it is $38 \%$ (CIAT, 1986, Jones, 1999). In order to minimize grain loss, small-scale farmers store bean grain for short period, about six months. Majority of them use mechanical control such as mixing grains with ashes (20\% of treated weight) as preventive measure. Likewise, use sand, lime, or other fillers. Apart from fillers, coating bean grains with edible vegetable oils $(5 \mathrm{ml} / \mathrm{kg})$ is more effective for six months period (e.g. peanut, maize, or soybean oil), however, oil may cause rancidity and prolong cooking time. The oil is effective in controlling both eggs and adult; in eggs, it penetrates and destroys them, while in adults it reduces oviposition and increases mortality (CIAT, 1986). As compared to ash or other fillers, oil treated grains are more attractive and does not affect marketability (CIAT, 1986). However, oil treatments are effective only at the small scale production level (CIAT, 1986).

In order to minimize grain losses, farmers try different approaches of control methods, which are termed, unorganized integrated pest management (IPM) principles (ash, lime, etc). Although many bruchids control technologies have been developed over the years, very few have reached the small-scale farmers who cannot afford pesticides. The pesticide use is well developed and include both curative and protective methods. The curative method involves the disinfestations using fumigants, and applied mainly in warehouses. Fumigants eliminates infestation at the time of treatment and leaves no residue on grains. The phosphine (aluminum phosphide) is the commonly used fumigants. It eliminates all stages of the insect, including those within the seed. Bean sacks are kept covered for 1-2 days after fumigation for gas to penetrate seed. It is very toxic to humans and should be applied only by technical experts. However, the bean grains are liable to re-infestation (CIAT, 1986). 
The protective methods use different pesticides which are applied before infestation occurs. Several of the storage pesticides are available in the market, however, in Rwanda, pyrethrins products from AgroPy company are more safe to consumer, since they are less toxic, do not have persistant residues and are organically certified.. The application of synthetic protective insecticides must always be carried out with care and adequate knowledge of product potential dangers to consumers. The farmers knowledge on risks associated with misuse of pesticides in unclear, while bean is staple food item consumed in every household of all Rwandans community and in all restaurants irrespective of category. Therefore, beans grains full of pesticides pause great risk to the community of all levels. The need to understand the perception of small scale farmers on losses caused by bean bruchid, control strategies and pesticide safe use in critical.

Therefore, the objective of this study was to establish the knowledge of small scale farmers on damage and losses caused by bruchids, control strategies applied and implication on food security, safety and nutrition in Rwanda.

\section{Methodology}

The study was conducted at Gatwaro cell in Rwaniro sector, Huye District in Rwanda during the month of May 2009, just before the season B harvesting in June. Gatwaro cell has 1631 households distributed in four villages (Gatwaro, Rumana, Amarongi and Nyakabuye). Rwaniro sector is one of 14 sectors of Huye District. The District is located at central plateau agro-ecological zone of Rwanda, with altitude range of 1500 and 2100 masl, annual rainfall of 1000 to $1600 \mathrm{~mm}$ and optimum temperature of $19^{\circ} \mathrm{C}$ (range $10^{\circ} \mathrm{C}-30^{\circ} \mathrm{C}$ ). We selected randomly 91 households from the four villages of Rwaniro sector using as follows: 23 households from each of the three villages (Gatwaro, Rumana and Amarongi) and 22 in Nyakabuye.village. 
The sample size of 91 was determined using the formular: $\mathrm{N}=\frac{N o}{\underline{1+\frac{N o}{N}}}$, where $N_{o}=\frac{(Z \infty)^{2} p^{*} q}{d^{2}}$

Whereas, the respondents in the each village were selected using lottery sorting from the list of farmers producing beans in the village. In order to collect data, we use questionnaires, face to face interview and personal observations of sample bean damage at each household. The questionnaire consisted of eight parts which were complementary and focused on bean bruchid problem, control strategies used by farmers and pesticides knowledge and use. The range of questions included gender of producers, age range, post-harvesting handling ( drying period, treatment of grains, storage materials, length of storage), bruchid problem, damage level and grain loss, effect of grain damage (on cooking, taste, germination and marketability), control methods, pesticides uses, source of knowledge and training on safe pesticides use. The above questions were based on needs to understand whether bean bruchids is major pest, how much damage it causes, knowledge of pests problem, management strategies and how safe are treated beans to consumers. In addition we interviewed input dealers in Huye town, which covered pesticides most sold, price range and advice given to buyers. In most cases farmers get advice from pesticides dealers than extension staff. We were interested in understanding pesticides commonly purchased by farmers for storage purpose and types of advice given for safe use. The data were recorded directly on the questionnaire on both structured and open ended questions at every individual household. Most fields were close to the household, however, we did not visit them, because our main interest was focused on postharvest handling and problems. The data were entered and analyzed using SPSS.17 statistical software program. The analysis focused on descriptive statistics as were interested to understand proportion of population who have challenge of bruchids and how they manage the problem. 


\section{RESULTS}

\section{Age and gender distribution}

Bean production was primarily subsistence and carried out manually mainly by women (57. 1\%). Majority of farmers had middle age, 36 and 65 years $(60.4 \%)$.(Table 1$)$.

Table 1: Age and gender distribution among beans growers in Rwaniro sector, Huye District, Rwanda, May 2009.

(i) Age distribution

Age range (years)

Frequency

Percent

18 to 35

24

26.4

36 to 65

55

60.4

Above 65

12

13.2

(ii) Gender distribution

Male

39

42.9

Female

52

57.1

\section{Bean storage period and grain loss from bruchid damage}


The farmers in Rwaniro sector stored bean grains for varying length depending on the amount produced and domestic needs. Majority of farmers stored for 6-12 months (63.8\%), followed by 3-6 months (22\%) (figure 1). After the harvest, $84.6 \%$ of farmers experienced considerable losses due to bruchid damage. The amount of loss in storage is reported in table 1 . The grain loss of $30 \%-100 \%$ was reported by $72.6 \%$ of farmers, although $30 \%$ loss was predominant and was reported by $37.4 \%$ of them (table 2 ) and only $27.5 \%$ had $0-10 \%$ losses (table 2. )

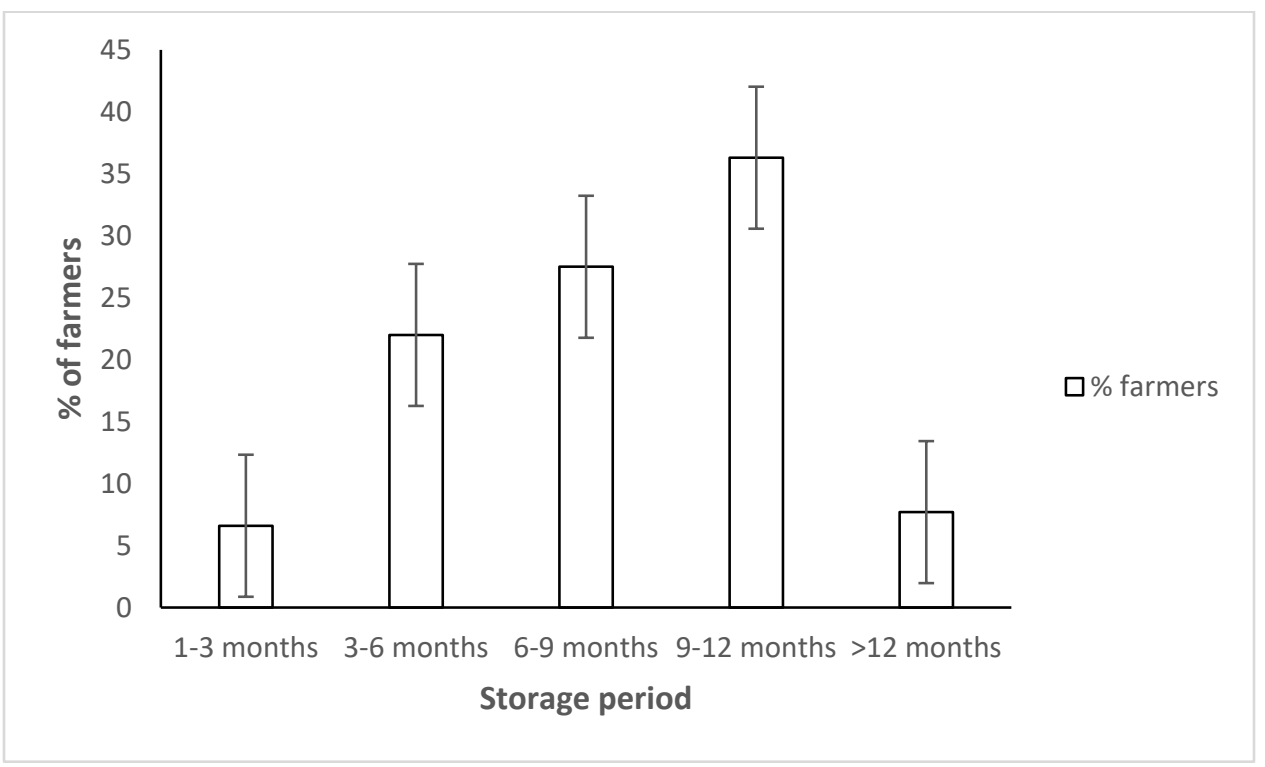

Figure 1. Storage period for bean grain and seed in Rwaniro sector, Huye district, May, 2009. 
Table 1: Estimation of grain loss from bruchid damage during storage period in Rusatira Sector, Huye District, mid altitude of Rwanda, assessed in May 2009.

\begin{tabular}{lccr}
\hline Loss categories & Loss $(\%)$ & Frequency & Percent \\
\hline None & 0 & 20 & 22.0 \\
Small & $<10$ & 5 & 5.5 \\
Medium & 30 & 34 & 37.4 \\
High & 50 & 16 & 17.6 \\
Moderate high & 60 & 12 & 13.2 \\
Very high & 100 & 4 & 4.4
\end{tabular}

\section{Reasons influencing farmers decision making on bruchid control before storage}

The study indicated that majority of farmers $(85.7 \%)$ treat beans before storage for preventing bruchid damage. Only $7.7 \%$ treat them to enable long storage period (Table 2).

Table 2: Reasons of treating beans before storage in Rwaniro sector, Huye District, May 2009 
Reasons of treating beans before storage

For long-term storage

Preventing bean bruchid attacks

Other reasons(keep them healthy)

Don't treat beans before storage
Frequency

7

78

1

5
85.7

1.1

\section{Percent}

7.7

5.5

\section{Materials used for beans storage}

Majority of farmers (63\%) use polyethylene bags, followed by earthenware pots (24\%) and gunny bags (9\%) (figure 2). Most farmers $(96.7 \%)$ didn't clean containers before adding new grain harvest, thus uncleaned containers, serving as main source of bruchid infestation.

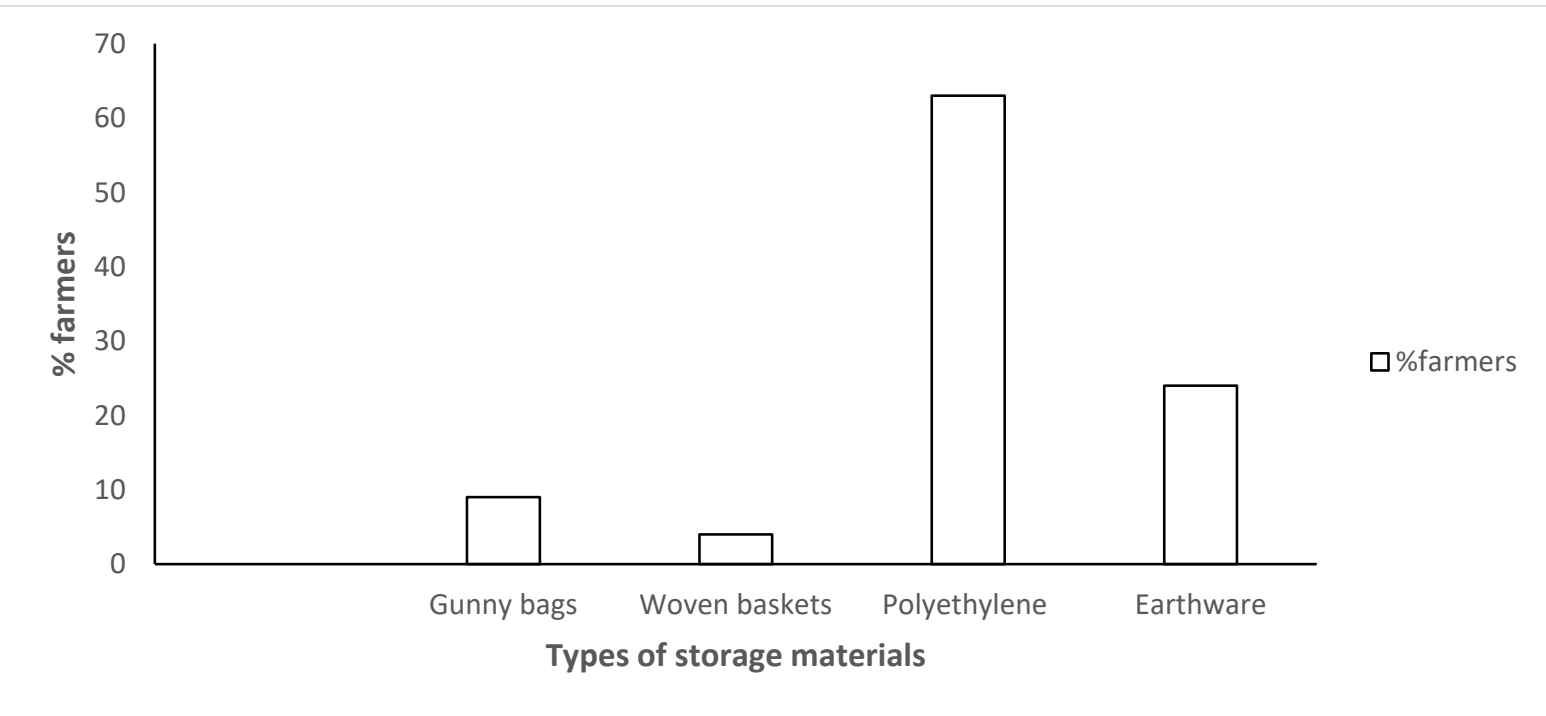

Figure 2: Storage materials used at farm level in Rwaniro sector, Huye district, May 2009.

Farmers knowledge of different bruchid control strategies, application and satisfaction 
Farmers applied different control methods. Majority of them (44.0\%) apply chemical followed by tradition methods $(39.6 \%)$. Some of them combined both chemical and traditional methods $(9.9 \%)$. A small number of farmers $(6.6 \%)$ did not treat bean grain before storage (table 3). Among 91 farmers in this study, 46 (50.5\%) indicated that insecticides use was more efficient in protecting the bean grains. Traditional methods (ash, lime or pepper etc) was less effective as it was reported as satisfactory by 20 (22\%) of farmers only, while $20.9 \%$ did not know

Table 3: Control measures against bean bruchids at Rwaniro secotor, Huye District, Rwanda, May 2009 Used control measures Frequency Percent

traditional method (ash, lime, pepper and mixtures etc)

chemical treatment

traditional and chemical methods

Do not treat beans

36

40

9

6
39.6

9.9

6.6

\section{Farmers awareness and knowledge of safe pesticides use, associate risks and training}

Farmers were not aware of risk of pesticides use, and were not trained (table 4). They were handling hazardous products without adequate knowledge and skill leading to misuse. From figure 3 a large number of farmers used their own knowledge (42\%) from other farmers, followed by input sellers (31\%). Due to lack of training, $99 \%$ of them use or sell grains immediately after treatment.

\section{Table 4: Training on pesticides safe use and application}


Trained in safe use

1

70

1.1

Not trained

Do not use pesticides
22.0

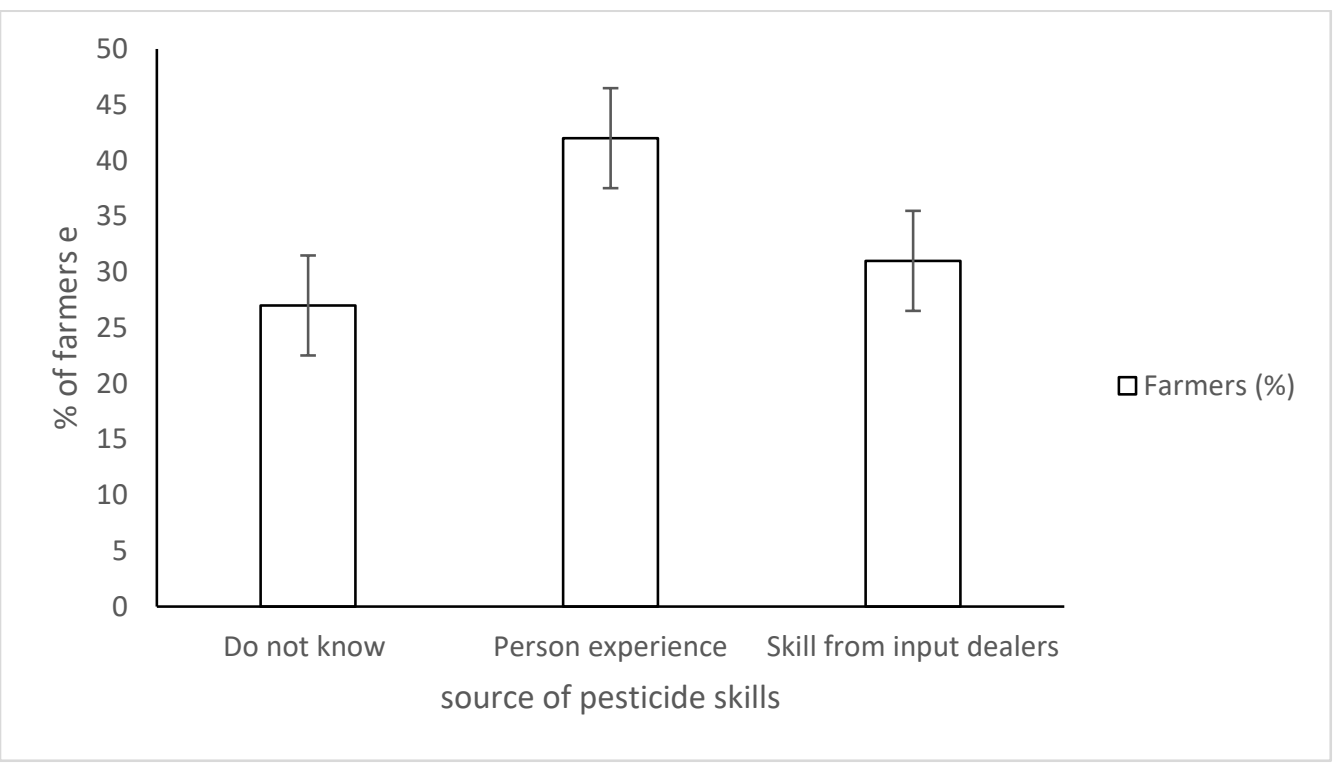

Figure 3: Knowledge on pesticides application and associated risks to users and consumers

\section{Effect of bruchid damaged grains on germination, cooking time and marketability}

The damage seed fail to germinate as reported by $46.2 \%$ of farmers Likewise, the damaged bean grains take long time to cook, and when ready, they have bad taste. Apart from quantitative loss, there is also qualitative loss from bruchid damage. The bruchid damaged bean grains are not easily sold and when sold, they are given lowest price, up to $50 \%$ or below of normal grain. 


\section{DISCUSSION}

.The storage insect pests are among biotic factors causing postharvest losses in developing countries (Hodges et al, 2011, Abate and Ampofo, 1996). Hence the control bean bruchid is an important activity in improving food security. The dry bean stored in inadequate environment deteriorates so easily especially in areas where temperatures are beyond the safe storage levels of moisture content (13.5\% MC) and relative humidity (70\% RH). The farmers in Rwaniro sector, stored their bean for different period depending on the amount produced and domestic needs. The storage period was 3-9 months (49.5\%), 9-12 months (36.3\%), and more than one year (7.7\%). Since it is known that infestation starts after first three months of storage (MINAGRI, 2002), and unclean storage facilities are major source of bean bruchids (CIAT. 1986), farmers should be trained in safe storage practices and bruchid control. The storage of beans at household level improves food security through availability, access, affordability and stability of supply.. Bean grains stored in good environment maintains its quality for a period up to one year and beyond, and are sold at very high the price during off season, leading to higher income and improved livelihood. Most farmers sell their beans soon after harvest at low price to avoid bruchid damage, leading to economic loss. In this study, bruchid was a major challenge during storage period, with high infestation starting after three months. The reported loss was variable and depended on storage period and conditions. $37.4 \%$ of farmers lost up to $30 \%, 35.2 \%$ lost $50 \%$ and aboveand only $27.5 \%$ had $0-10$ grain loss. These results are in agreement with Jones (1999) and Abate and Ampofo (1996) who reported grain loss of 20$30 \%$. Bruchid is a great challenge and threat to food security and nutrition in Rwanda. Apart from food security, the damaged beans are not easily marketable, have poor quality to consumers, and when planted do not germinated (van Schoonhoven et al, 1986). To minimize losses of grains in store, farmers used both traditional (39.6\%) and chemical (44\%) control methods, and few of them (9.9\%) combine both methods. 
Majority of farmers ( 90\%) applied available technologies and still got losses during storage period. Therefore, there is great need to review the current recommended bruchid control methods and make available to farmers. In this study ,only $1.1 \%$ of farmers was trained in pesticides application, as a result majority of them applied pesticides wrongly, which has risk to both farmers and consumers. In this study, $31 \%$ of farmers depended on input dealers to get pesticides information, and $41 \%$ on thei own experience. Whereas, Rwanda has high population density, and beans is a major source of protein second to meat, there is a great need to minimize grain loss in quantity and quality during storage period, hence bruchid control is essential. This is important because the agro climatic condition of Rwanda has temperature $\left(20-35^{\circ} \mathrm{C}\right)$ and relative humidity $(65-80 \%)$ favorable for development of bruchids, as a result, the bruchid infestation of stored bean reaches $10 \%$. after first three months period only (MINAGRI, 2002).

Basing on the findings from this study, the capacity building of farmers, in particular women, on bruchid control, pesticides safe use and better storage; will reduce beans grain losses, improve availability, income, livelihood and save environment (WB, 2006, WB, 2010, Hodges, et al, 2011). The dependence of farmers on input sellers for pesticide technology should be reversed through training on improved production and storage technologies. The future research should focus on effect of climate change on storage condition at farm level and implication on bruchid infestation at different agroecological zones of Rwanda.

\section{Conclusion and recommendation}

This study has confirmed that bean bruchid is still a major pest in stored dry bean grains in mid altitude of Rwanda. The farmers lack training in bruchid management. Therefore, farmers need training on bean best practices recommended for control of bruchids and safe use of pesticides, in particular women who form majority of beans

producers. The mapping of altitude limit for bush beans as suitable sites and level of bruchid infestation may 
guide research for reducing postharvest losses and bruchid damage. The cost benefit analysis of bruchid control and implication in food security would be useful for both farmers and policy makers.

\section{REFERENCES}

Abate, T. and Ampofo, J.K.O., 1996. Insect pests of beans in Africa: their ecology and management. annual Review of Entomology , 41, pp. 45-73

Catherine, L. and Jeffrey, D., 2014. Impact of improved beans varieties on food security in Rwanda. paper presented at Agricultural and Applied economics association, 2014, Annual meeting, Minneapolis, July, 27-29, 2014.

CIAT, Nov. 1986. Principal insects attacking dry stored beans, 2nd edition

De Lucia, M. and Assennato, D., 1994. Agricultural engineering in development: postharvest operations and management of food grains. FAO Agricultural services Bulletin, no 93, Rome, FAO.

Haines, C.P., 1991. Insect and Arachnids of Tropical stored product. Their biology and identification. Training manual, 2nd edition.

Hodges, R.J. Buzby, J.C. and Benett, A., 2011. Postharvest losses and waste in developed and less developed countries: opportunities to improve resource use. Journal.of Agricultural. Sciences. 149 , pp. $37-45$

Howe, R.W. and. Currie, J.E., 1964. Some laboratory observations on rates development and oviposition of several species of bruchidae breeding in stored pulses. Bulletin. of Entomological. Research, 55, pp. 437-477. 
Jones, A.L., 1999. Phaseolus Beans: Postharvest operations. Cali, Colombia, CIAT, 24 pp.

MINAGRI, 2002. Indicateurs du développement au Rwanda. Kigali. Rwanda. 379 pp.

MINAGRI, 2004. Strategic plan for Agricultural Transformation in Rwanda, Kigali, Rwanda, MINAGRI. 122 pp.

Musoni, A., 2012. Making bean market work : secondary data on information gaps in the beans value chain in Rwanda. Report submitted to Kilimo Trust. 49.p.

Sperling, L. and Muyaneza, S., 1995. Intensifying production among smallholder farmers: impact of improved climbing beans in Rwanda. Africa Crop Science, Vol. 3 no 1, pp. 117-125.

van Schoonhoven, A., Cardona, C. and Valencia, C.A., 1986. Main insect pests of stored beans and their control.Sstudy guide. Cali, Colombia, CIAT. 40 p.

World Bank, 2010. Missing food. The case of postharvest grain losses in Sub saharan Africa. Washington DC. The World Bank.

World Bank, 2006. Enhancing agricultural innovation: How to go beyond the strengthening of research systems. Washington, DC. The World Bank. 